\title{
Role of macrophyte life forms in driving periphytic microalgal assemblages in a Brazilian reservoir
}

\author{
Ubirajara L. FERNANDES, " Elaine C.C. de OLIVEIRA, Sírleis R. LACERDA \\ Departamento de Ciências Biológicas, Laboratório de Botânica, Universidade Regional do Cariri, URCA, Rua Coronel Antônio Luiz \\ n. 1161, CEP 63.100-000, Bairro Pimenta, Crato, Ceará, Brazil \\ *Corresponding author: ubiralf@gmail.com
}

\begin{abstract}
Macrophytes play several roles in aquatic ecosystems, including the provision of habitat for many aquatic organisms, especially the periphyton. The aims of this study were to characterize the structure of periphytic microalgal assemblages on different aquatic macrophyte life forms in order to establish similarities between assemblages from nearby sampling sites. We hypothesized that i) aquatic macrophytes with different life forms and morphological characteristics could differently influence the structure of the periphyton; and ii) that the greatest similarity in periphyton composition should be observed among macrophytes that occupy the same sampling site. The study was conducted from 2006 to 2008 in the Thomaz Osterne de Alencar reservoir (Crato City, Ceará State, Brazil) and involved the taxonomic surveying of microalgae attached to five different macrophytes with the application of structural descriptors (richness, abundance, frequency, diversity and equitability). A total of 127 taxa, of which 44\% belonged to the Chlorophyta, were identified. The microalgae assemblages showed high species richness on Salvinia auriculata Aubl., a free-floating macrophyte, and large abundance on Apalanthe granatensis (Humb.\& Bonpl.) Planch., a submerged anchored macrophyte. ANOVA indicated that periphyton significantly varied among the macrophytes investigated, and nearby sampling sites showed no structural similarities in microalgal assemblages. In general, we can conclude that the structure of periphyton assemblages is influenced by the substrate (1.e., macrophyte organ), as this can not only promote high diversity and equitability but can also be a predictor of dissimilarity in the distribution and frequency of occurrence of microalgae. These results reinforce the findings of other studies that have shown that macrophytes play an important role in structuring the periphyton assemblages.
\end{abstract}

Key words: Microalgae distribution; periphyton; natural substrate; aquatic vegetation.

Received: August 2014. Accepted: July 2015.

\section{INTRODUCTION}

The periphyton is defined as a group of organisms (e.g., bacteria, microalgae, and fungi) and organic matter attached to different substrate types in an aquatic environment (Wehr and Sheath, 2003). Microalgae are the most representative constituents of these assemblages, with a predominance of Cyanobacteria, chlorophyceans, and diatoms (Lowe, 1996; Stevenson, 1996). These microalgae live mainly on macrophytes in a wide range of freshwater environments such as rivers, lakes, reservoirs, and wetlands (Cantonati and Lowe, 2014). This is possible because macrophytes contribute to the physical structure of the colonized aquatic habitats, reduce water velocity (Dodds and Biggs, 2002), and increase habitat complexity by providing refuge, foraging, and reproduction areas for other organisms (Thomaz and Cunha 2010). Through their architectural morphology, macrophytes may influence the distribution, abundance, and composition of other aquatic organisms, such as the periphyton and invertebrates, that live on their underwater array of leaves, stems, and roots (Thomaz et al., 2008; Hinojosa-Garro et al., 2010; Hansen et al., 2011; Lucena-Moya and Duggan,
2011; Choi et al., 2014). Macrophytes include species with different life forms (e.g., floating, emerged, and submerged) that act to maintain the integrity of aquatic ecosystems, and have strong effects on productivity and nutrient cycling (Carpenter and Lodge, 1986; Thomaz and Cunha, 2010). The morphological complexity of macrophytes has also been shown to influence the primary productivity of microalgae in a habitat (Lalonde and Downing, 1991; Cardinale et al., 2002; Avigliano et al., 2014). Different types of macrophytes may be used as substrate for different taxonomic compositions of microalgae (Messyasz et al., 2009). For example, certain macrophytes can inhibit the growth of periphytic microalgae by attracting herbivores that clean their surface (Jones et al., 2000). In addition plant age, allelopathic substances, and the physico-chemical characteristics of water can also affect assemblage structure (Mulderij et al., 2003; Mormul et al., 2010). It has been widely recognized that macrophytes with greater morphological complexity (e.g., compound leaves and floating adventitious roots) show both greater diversity and abundance of associated organisms (Lucena-Moya and Duggan, 2011). However, when 
different macrophytes occupy the same site, the periphyton assemblages may have similar compositions (Messyasz and Kuczyńska-Kippen, 2006).

Previous research has shown that the development of periphytic microalgae, both in terms of taxonomic diversity and function, is heavily dependent on physical, chemical, and environmental factors (Biggs and Close, 1989; Lalonde and Downing, 1991; Biggs and Stokseth, 1998; Hinojosa-Garro et al., 2010; Cuassolo et al., 2011). The results obtained by comparing natural and artificial substrates indicated that macrophytes appear to have the greatest influence on the taxonomic composition (Jones et al., 2000; Vercellino and Bicudo, 2006; Felisberto and Rodrigues, 2010) and biomass production of periphytic microalgae (Guariento et al., 2007).

The aim of this study was to integrate the results obtained by the above-mentioned researches investigating the role of macrophyte organs in driving the structure (richness, abundance, frequency, diversity and equitability) of periphyton assemblages. The working hypotheses were that the different organs of aquatic macrophytes and morphological characteristics are able to influence periphyton structure in a characteristic way and that the greatest similarity in periphyton composition can be observed among macrophytes that occupy the same sampling site.

\section{METHODS}

Sampling was conducted monthly in the Thomaz Osterne de Alencar reservoir (Crato City, Ceará State, Brazil) (Fig. 1) from May 2006 to June 2008. This reservoir has an estimated storage capacity of $28,780,000 \mathrm{~m}^{3}$ (Pinheiro et al., 2011). The study area is located in the northeast of Brazil. This region presents a semiarid climate with welldefined dry (from July to January) and rainy (from February to June) seasons, with an average annual rainfall of approximately $600 \mathrm{~mm}^{3}$ (Funceme, 2012). Samples were collected at six sites (Fig. 1) that were selected based on the great similarities in macrophyte assemblages.

Periphyton sampling was performed first by manually squeezing of similar organ ratios from submerged parts of 5 different macrophytes (Tab. 1), after which they were subjected to water jets (to sample loosely attached periphyton forms). The 5 different macrophytes sampled were: Chara rusbyana Howe, Salvinia auriculata Aubl., Apalanthe granatensis (Humb. \& Bonpl.) Planch., Polygonum hispidum Kunth and Nymphaea pulchella (Salisb) DC. characterized by different life forms (i.e., submerged, free-floating, submerged anchored, and with floating leaves, respectively) and morphologies, occurring along different banks of the reservoir which present very similar
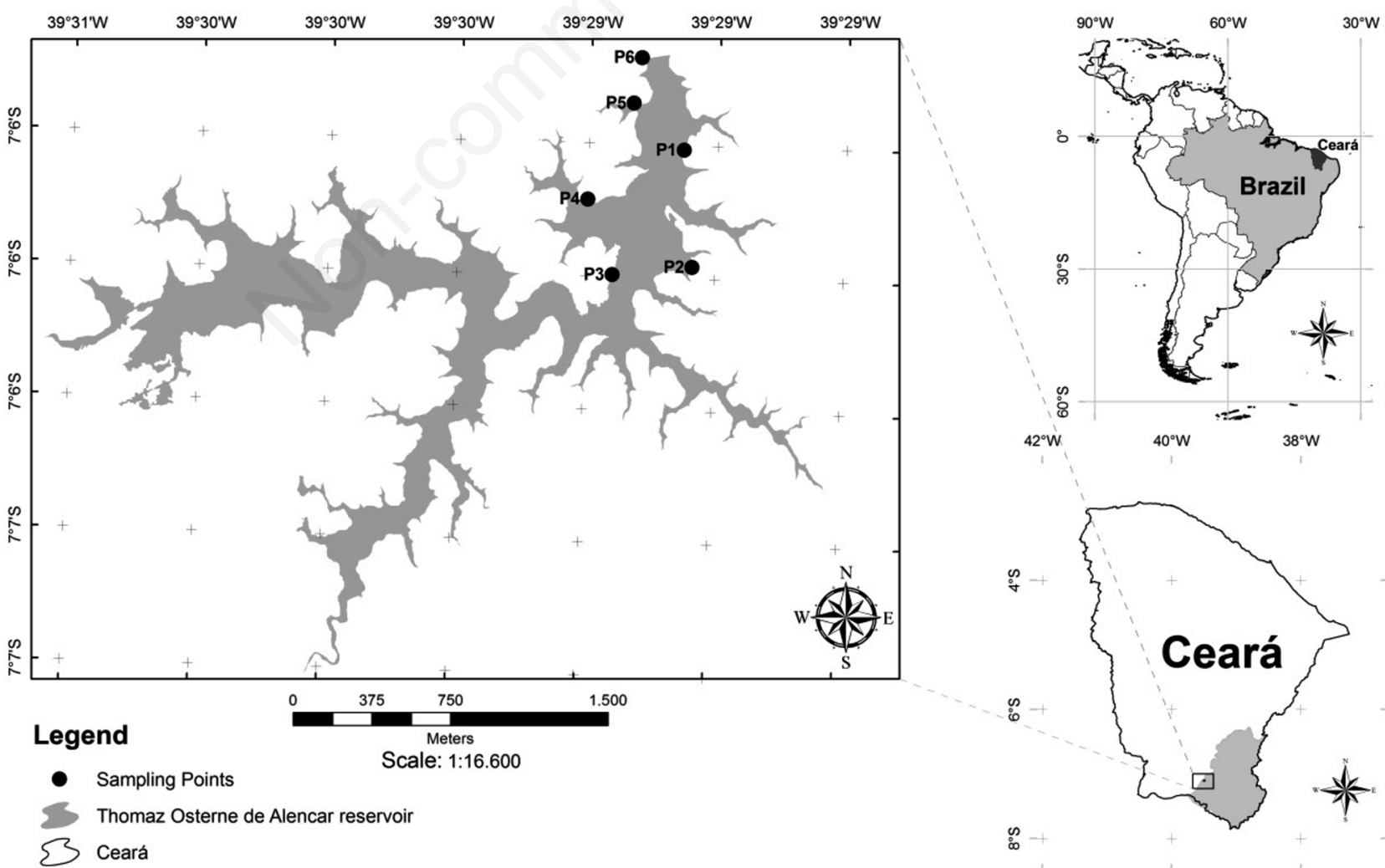

Fig. 1. Map of of Thomaz Osterne de Alencar reservoir (Crato City, Ceará State, Brazil) and sampling sites. 
physiognomic characteristics (Fig. 1; Tab. 1). The periphytic microalgae were placed in suitable containers and fixed in 4\% neutral formalin (Newell and Newell, 1977). However, it was not always possible to collect periphyton samples from all the selected macrophytes in the different experimental sites due to relative low frequency of C. rusbyana, S. auriculata, and N. pulchella; the overall sampling effort is reported in the Tab. 1.

The qualitative analysis of microalgae consisted on the identification of taxa under a light microscope at 100× and $400 \times$ magnifications. Two slides per sample were observed. The identification and classification of taxa were conducted based on the following sources: Mizuno (1968), Compère (1976), Parra et al. (1983), Round et al. (1992), Xavier (1994), Sant'Anna (1997), Brassac and Ludwig (2003), Wehr and Sheath (2003), Bicudo and Menezes (2005), Sophia et al. (2005), and Soares et al. (2007). For each macrophyte and sampling site investigated, data from the total record over the sampled period were used for the calculation of richness, frequency, abundance, diversity, and equitability. The species richness was estimated by considering the number of taxa occurring in the reservoir. To estimate the diversity of the periphyton taxa, Shannon's diversity $\left(\mathrm{H}^{\prime}\right)$ and Pielou's equitability $(\mathrm{J})$ indices were calculated using the abundance data. The occurrence frequency was calculated by taking into account the number of times each taxon occurred in the samples according to the following formula:

$\mathrm{F}=\mathrm{P} \times 100 / \mathrm{p}$

where: $\mathrm{P}=$ is the number of samples containing the species and $\mathrm{p}=$ the total number of samples examined $(\mathrm{n}=109)$. The following classification criteria were established: very frequent $(>70 \%)$, frequent $(\leq 70 \%$ and $>30 \%)$, low frequent $(\leq 30 \%$ and $>10 \%)$ and sporadic $(\leq 10 \%)$ (Mateucci and Colma, 1982).

Periphyton abundance was estimated following the recommendations by Lobo and Leighton (1986) and the data expressed using a Whittaker (1975) abundance diagram, where where the $\mathrm{x}$-axis ranks species in decreasing order of abundance and the $y$-axis shows the relative of species. The data were also tested for normality (Kolmogorov-Smirnov test), homogeneity of variance (Levene's test), and for possible differences between the means (to compare periphytic microalgae assemblages among macrophytes) using analysis of variance (ANOVA), and subjected to Tukey's test with a significance level of $5 \%$. The analyses were performed using STATISTICA 7.0 (StatSoft Inc., 2004).

To test the relationships between the sampling sites and macrophytes, cluster analysis was performed using the Jaccard similarity index, where the results were obtained by evaluating the percentage of similarity between the sampled points. The analyses were performed using PAST (Hammer et al., 2001).

\section{RESULTS}

The periphyton assemblages in the Thomaz Osterne de Alencar reservoir was represented by a richness of 127 taxa (Supplementary Tab. 1), which are divided into the following divisions: Chlorophyta (44\%), Bacillariophyta (29.2\%), Cyanobacteria (20.5\%), Euglenophyta (3.9\%), Chrysophyta (0.8\%), Dinophyta (0.8\%), and Rhodophyta (0.8\%) (Tab. 2).

The greatest species richness, equal to 112 taxa (amounting to about $88 \%$ of the total microalgal diversity), was recorded on the roots of $S$. auriculata, followed by A. granatensis. (109), P. hispidum (102), C. rusbyana (83), and N. pulchella (81) (Supplementary Tab. 1).

Regarding the relative abundances of periphytic microalgae between sampling sites and macrophytes, the most widespread divisions were Chlorophyta, Bacillariophyta, and Cyanobacteria, while the less abundant divisions, ranked in a decreasing order, were Euglenophyta, Chrysophyta, Dinophyta, and Rhodophyta (Tabs. 2 and 3). With respect to the distribution of the microalgal division occurrence frequency, C. rusbyana and P. hispidum. exhibited the highest percentages of "very frequent" species of Dinophyta. However, on S. auriculata, A. granatensis, and $N$. pulchella the algal divisions with the highest percentage of "very frequent" species were Bacillariophyta, Cyanobacteria, and Chlorophyta (Fig. 2).

Tab. 1. Sampled aquatic macrophytes and their life form, with their sampling sites in the Thomaz Osterne de Alencar reservoir.

\begin{tabular}{|c|c|c|c|c|c|c|c|c|c|}
\hline \multirow{2}{*}{\multicolumn{2}{|c|}{$\begin{array}{l}\text { Aquatic macrophytes } \\
\text { Family }\end{array}$}} & \multirow[b]{2}{*}{ Life form } & \multirow[b]{2}{*}{$\mathrm{OCP}$} & \multicolumn{6}{|c|}{ Sampling sites } \\
\hline & & & & P1 & $\mathbf{P} 2$ & P3 & P4 & P5 & P6 \\
\hline Characeae & Chara rusbyana Howe. & Submerged & Stalk & $\mathrm{x}$ & $\mathrm{x}$ & $\mathrm{x}$ & - & - & $\mathrm{x}$ \\
\hline Salviniaceae & Salvinia auriculata Aubl. & Free-floating & Roots & $\mathrm{x}$ & $\mathrm{x}$ & $\mathrm{x}$ & $\mathrm{x}$ & $\mathrm{x}$ & - \\
\hline Hydrocharitaceae & $\begin{array}{c}\text { Apalanthe granatensis } \\
\text { (Humb. \& Bonpl.) Planch. }\end{array}$ & Submerged anchored & stalk and leaves & $\mathrm{x}$ & $\mathrm{x}$ & $\mathrm{x}$ & $\mathrm{x}$ & $\mathrm{x}$ & $\mathrm{X}$ \\
\hline Polygonaceae & Polygonum hispidum Kunth & Emerged & roots and stalk & $\mathrm{x}$ & $\mathrm{x}$ & $\mathrm{x}$ & $\mathrm{x}$ & $\mathrm{x}$ & $\mathrm{x}$ \\
\hline Nymphaeaceae & Nymphaea pulchella (Salisb) DC. & With Floating Leaves & petiole and leaves & - & $\mathrm{x}$ & $\mathrm{x}$ & $\mathrm{x}$ & - & $\mathrm{x}$ \\
\hline
\end{tabular}

OCP, Organ of collection of periphyton; P1 to P6, sampling sites (see Fig. 1); $x$, presence; -, absence. 
Regarding the overall occurrence frequency, relatively few taxa were very common at the reservoir scale, while a greater number were sporadic. However, the occurrence frequency of periphytic species varied among macrophytes; C. rusbyana primarily harboured infrequent taxa and did not present sporadic taxa (Figs. 2 and 3). On this macrophyte, the very frequent taxa were the diatoms $E p$ ithemia sp., Navicula radiosa Kützing, Rhopalodia gibba (Ehrenberg) O. Müller, Thalassionema nitzschioides
Grunow, and Thalassiothrix frauenfeldii Grunow, and the chlorophycean Closterium sp., all of which exhibited $100 \%$ frequency (Supplementary Tab. 1).

The more frequent taxa were present on $S$. auriculata and P. hispidum (Fig. 3). These two macrophytes exhibited similar assemblages dominated by Amphora sp., $N$. radiosa, $T$. nitzschioides, and $T$. frauenfeldii (diatoms that occurred at $100 \%$ frequency similarly to the results observed for C. rusbyana). Only on P. hispidum, the diatom

Tab. 2. Relative abundance (\%) of periphytic microalgae on macrophytes in the Thomaz Osterne de Alencar reservoir.

\begin{tabular}{|c|c|c|c|c|c|c|}
\hline & C. rusbyana & S. auriculata & A. granatensis & P. hispidum & N. pulchella & All macrophytes \\
\hline Cyanobacteria & 20.4 & 20.5 & 20.1 & 21.5 & 24.6 & 20.5 \\
\hline Euglenophyta & 3.6 & 4.4 & 2.7 & 1.9 & 2.4 & 3.9 \\
\hline Chrysophyta & - & 0.8 & 0.9 & 0.9 & - & 0.8 \\
\hline Chlorophyta & 43.3 & 43.7 & 44.0 & 40.1 & 40.7 & 44.0 \\
\hline Dinophyta & 1.2 & 0.8 & 0.9 & 0.9 & 1.2 & 0.8 \\
\hline Rhodophyta & - & - & 0.9 & 0.9 & 1.2 & 0.8 \\
\hline
\end{tabular}

Tab. 3. Relative abundance (\%) of the total periphytic microalgae by sampling sites in the Thomaz Osterne de Alencar reservoir. From P1 to P6 sampling points.

\begin{tabular}{lccccccc} 
& P1 & P2 & P3 & P4 & P5 & P6 & All sites \\
Cyanobacteria & 21.1 & 20.3 & 20.0 & 21.5 & 19.0 & 21.7 & 20.4 \\
Euglenophyta & 2.8 & 3.8 & 3.6 & 2.1 & 2.8 & 2.5 & 3.9 \\
\hline Bacillariophyta & 28.8 & 28.1 & 32.7 & 32.2 & 32.4 & 35.8 & 29.1 \\
Chrysophyta & 0.9 & 0.9 & 0.9 & - & 0.95 & - & 0.7 \\
\hline Chlorophyta & 44.2 & 45.6 & 40.9 & 41.9 & 42.9 & 37.1 & 44.0 \\
Dinophyta & 0.9 & 0.9 & 0.9 & 1.0 & 0.9 & 1.2 & 0.7 \\
\hline Rhodophyta & 0.9 & - & 0.9 & 1.0 & 0.9 & 1.2 & 0.7 \\
\hline
\end{tabular}

P1 to P6, sampling sites (see Fig. 1).

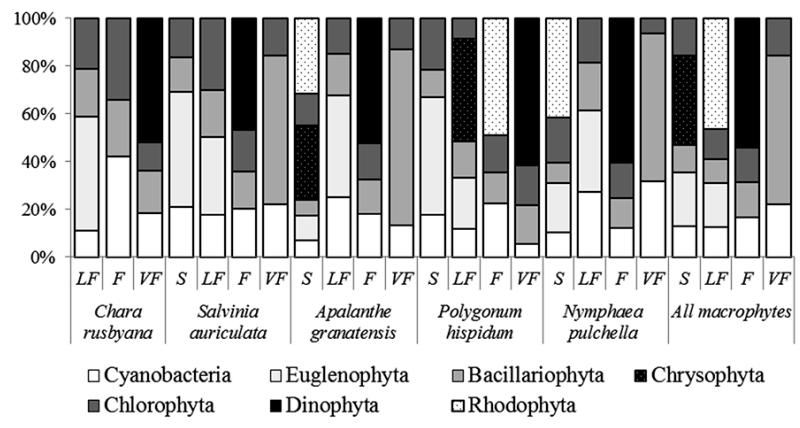

Fig. 2. Percentage from frequency of occurrence of periphytic microalgae on macrophytes in the Thomaz Osterne de Alencar reservoir. VF, very frequent; F, frequent; LF, low frequent; S, sporadic.

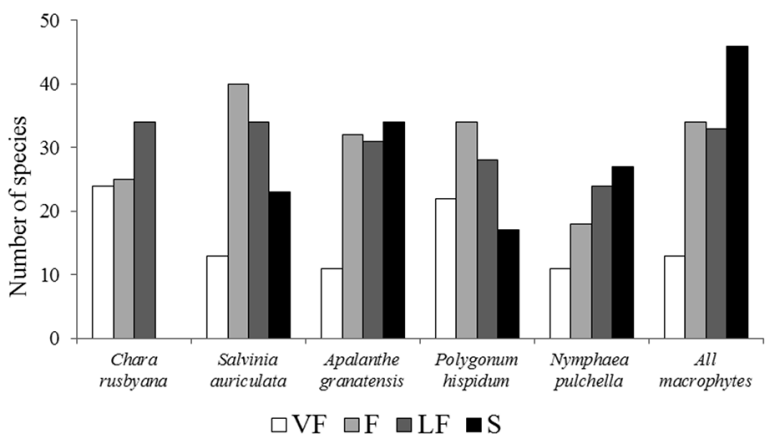

Fig. 3. Richness percentage of periphytic microalgae by frequency of occurrence among aquatic macrophytes in Thomaz Osterne de Alencar reservoir. VF, very frequent; F, frequent; LF, low frequent; S, sporadic. 
Gomphonema sp. was a specific taxon of this assemblage hosted at $100 \%$ frequency (Supplementary Tab. 1). On the contrary, sporadic taxa were predominant on A. granatensis and N. pulchella (Fig. 3). On A. granatensis, the very frequent taxa consisted of the diatoms Eunotia sp. (92.8\%), Epithemia sp., Gomphonema sp., N. radiosa, and T. nitzschioides (90.4\%) (Supplementary Tab. 1). On N. pulchella, only the diatom Epithemia sp. was present at a frequency of 100\% (Supplementary Tab. 1).

According to the Whittaker diagram of abundance, the periphytic microalgal taxa were more abundant on $A$. granatensis, with 9 species that fall in the highest abundance category: Eunotia sp, Epithemia sp., Gomphonema sp., N. radiosa, T. nitzschioides, Amphora sp., Phormidium sp., T. frauenfeldii, and Oedogonium sp. Among the other macrophytes studied, microalgae were present in the greatest abundance in decreasing order on S. auriculata, P. hispidum, N. pulchella, and C. rusbyana (Fig. 4). H' values revealed high levels of microalgal diversity in the studied area, with $S$. auriculata showing the greatest diversity among macrophytes $\left(H^{\prime}=4.4\right)$, followed by $A$. granatensis and $P$. hispidum (both with $\mathrm{H}^{\prime}=4.3$ ). In contrast, the lowest microalgal diversity value was observed on $N$. pulchella $\left(\mathrm{H}^{\prime}=4.0\right)$ (Fig. 5). However, all macrophytes showed J' values greater than 0.9 , indicating a uniform distribution of the periphyton across the sampled sites and macrophyte life forms (Fig. 5). The periphytic microalgae showed significant differences among macrophytes (ANOVA, $\mathrm{F}_{1,96}=26.6$; and $\mathrm{P}<0.01$ ). However, the Tukey's test did not show significant differences between C. rusbyana and N. pulchella $(\mathrm{P}=0.99)$, and between $P$. hispidum and A. granatensis $(\mathrm{P}=0.71)$. Cluster analysis showed that high assemblage similarities were only present between A. granatensis and S. auriculata at sampling sites 1 and 2. Conversely, the macrophytes occurring at sampling site 6 showed the greater dissimilarity in terms of their periphytic microalgal assemblages (Fig. 6).

\section{DISCUSSION}

Periphyton assemblages showed high species richness in the sampled reservoir. Most of the taxa recorded colonizing indifferently all the macrophytes investigated. The high species richness and diversity of periphyton in this reservoir can be related to the characteristics of the macrophyte banks at the particular sample sites, which present very similar physiognomic characteristics. These microalgal taxa benefited from the reservoir sector in which they live, the coastal region. This is a habitat of greater dynamism and a place that can easily be colonized by macrophytes, which in turn, allow the colonization of periphytic microalgae (Biolo et al., 2015).

The critical role played by macrophyte life forms in driving periphyton was observed, demonstrating that pe-

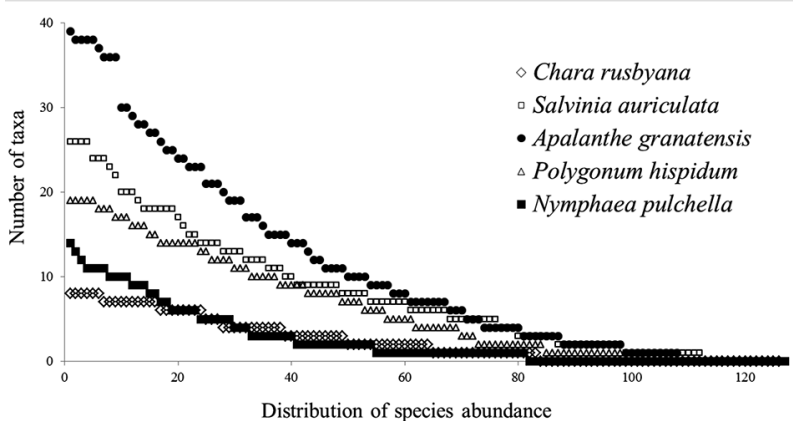

Fig. 4. Whittaker diagram with the taxa of periphytic microalgae aligned in order of number of taxa by relative abundance.

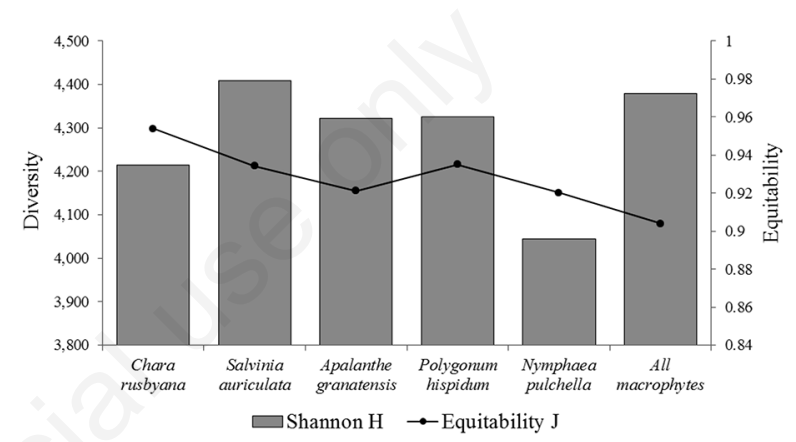

Fig. 5. Diversity and equitability indices of taxa of periphytic microalgae assemblages on macrophytes in Thomaz Osterne de Alencar reservoir.

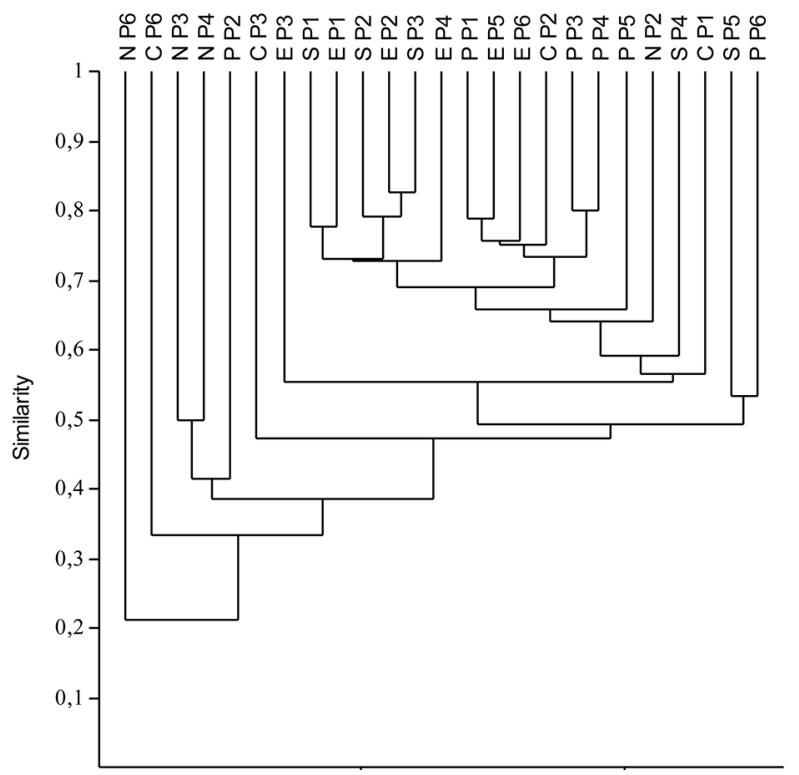

Fig. 6. Cluster analysis by the Jaccard similarity of periphytic microalgae assemblages among macrophytes and sampling sites in Thomaz Osterne de Alencar reservoir. C, Chara rusbyana; S, Salvinia auriculata; E, Apalanthe granatensis; P, Polygonum hispidum; N, Nymphaea pulchella; P1 to P6, sampling sites. 
riphyton differs among different substrates. A possible explanation is that the substrate can affect the interactions between these microorganisms. Microalgal assemblages within a sampling site tend to be more similar than assemblages from different sites, although a single sampling site can generate variable microalgal assemblages on different macrophytes (Lowe and LaLiberte, 2007; Messyasz et al., 2009). The periphytic assemblages showed little similarity among the macrophytes investigated, even those occurring at the same sampling sites. It is possible that the microalgae have developed distinct and species-specific mechanisms of colonization and persistence depending on the substrate. Hence, the observed periphyton differences may be related to the architecture and roughness of macrophytes as suggested by other studies (Thomaz et al., 2008; Sultana et al., 2010; Thomaz and Cunha, 2010). These plants can also determine the periphyton composition via the release of organic compounds that inhibit the colonization of certain species of algae, this was observed for Chara species, which interfere with the growth and establishment of various microalgae assemblages (Mulderij et al., 2003). The most abundant and common microalgal taxa belonged to the divisions Chlorophyta, Bacillariophyta, and Cyanobacteria, a very wide group of algae that exhibit multiple ways of fixing and establishing on substrates (Barsanti and Gualtieri, 2006). These strategies include mucilaginous sheaths, stems for fixing to the substrate, excretory pores, and differentiated basal cells that facilitate adhesion to the substrate (Barsanti and Gualtieri, 2006). These characteristics promote efficient colonization and rapid growth in substrates and have been observed in other lentic environments (Stevenson, 1996; Vercellino and Bicudo, 2006; Felisberto and Rodrigues, 2010; Ferreira et al., 2011).

Our results showed that macrophytes influence the distribution patterns and frequency of microalgae, particularly of those that are loosely attached to the substrate. This was evident when considering the occurrence of chlorophyceans Zygnemaphyceae (e.g., Cosmarium and Staurastrum genera), because, according to literature, these genera do not present specialized structures for fixation to substrates, but their frequency is positive influenced by the biomass of the colonized macrophyte stands (Murakami et al., 2009). Some microalgal taxa occurred more frequently on certain macrophyte species because these plants have greater morphological complexity, allowing taxa such as the diatoms Pinnularia sp., Nitzschia $\mathrm{sp}_{2}$ and Gyrosigma sp., to occur preferentially on A. granatensis, S. auriculata, and N. pulchella, as opposed to P. hispidum and C. rusbyana, which have common microalgae species to other macrophytes. A. granatensis, S. auriculata, and N. pulchella have different morphological structures and complexity (e.g., small and verticillated leaves, adventitious roots, and extensive petiole and leaf), and may favour only algae with fixation structures adapted to their particular structure. In general, more complex habitats lead to greater species diversity (Thomaz et al., 2008), and this pattern can be analysed by comparing the morphology of all the studied macrophytes.

In general, diatoms are specialized, through the use of attachment stems and pores, in colonizing substrates that exhibit morphological characteristics that facilitate their attachment and persistence (Barsanti and Gualtieri, 2006). This group of algae is present from the start of the colonization process and is abundant at advanced colonization stages (Felisberto and Rodrigues, 2010). They also show several advantages regarding resource utilization when compared with other algae that constitute the periphyton (Hinojosa-Garro et al. 2010).

The observed differences in the composition and relative abundance of algal species between assemblages can be explained by the type of colonization that microalgae species use in different habitats due to the different morphological characteristics of the studied macrophytes. The influence of macrophyte morphology in periphyton assemblages has been reported in other studies that showed that microalgae develop substrate preferences during the colonization stage on macrophytes (Villeneuve et al., 2010; Schneck et al., 2011). Regarding the type of macrophytes used as substrates, diatoms are strongly associated with macrophytes of the Hydrocharitaceae family because these plants are completely submerged and have a very complex structure that facilitates colonization by microalgae. Similar results were obtained by Messyasz and Kuczyńska-Kippen (2006). Species that live in environments with greater morphological complexity exhibit minor mode clustering and a wide range of functional characteristics, yielding greater diversity than in more homogeneous areas owing to the increased availability of niches (Pacini et al., 2009).

\section{CONCLUSIONS}

In general, we can conclude that the structure of periphyton assemblages is influenced by the macrophyte substrate, as this can not only promote high diversity and equitability but can also be a predictor of dissimilarity in the distribution and occurrence frequency of microalgae. The results of this research reinforce the findings of other studies that have shown that macrophyte life forms and their morphological complexity play an important role in structuring periphyton assemblages.

\section{ACKNOWLEDGMENTS}

The authors thank the Conselho Nacional de Desenvolvimento Científico e Tecnológico (CNPq) - a Brazilian financial institution - for the scientific initiation scholarship awarded to the first author. 


\section{REFERENCES}

Avigliano L, Vinocur A, Chaparro G, Tell G, Allende L, 2014. Influence of re-flooding on phytoplankton assemblages in a temperate wetland following prolonged drought. J.Limnol. 73:247-262.

Barsanti L, Gualtieri P, 2006. Algae: anatomy, biochemistry and biotechnology. CRC Press, New York: 301 pp.

Bicudo CEM, Menezes M, 2005. [Gênero de algas continentais brasileiras: chave de identificação e descrição].[Book in portuguese]. RIMA, São Carlos: 508 pp.

Biggs BJF, Close ME, 1989. Periphyton biomass dynamics in gravel bed rivers: the relative effects of flows and nutrient. Freshwater Biol. 22:209-231.

Biggs BJF, Stokseth S, 1998. Hydraulic habitat suitability for periphyton in rivers. Regul. River. 12:251-261.

Biolo S, Algarte VM, Rodrigues L, 2015. Composition and taxonomic similarity of the periphytic algal community in different natural substrates in a neotropical floodplain, Brazil. Afr. J. Plant. Sci. 9:17-24.

Brassac NM, Ludwig TAV, 2003. [Fragilariaceae (Bacillariophyceae) de rios da bacia do Iguaçu, Estado do Paraná, Brasil].[Article in Portuguese]. Rev. Bras. Bot. 26:311-318.

Cantonati M, Lowe RL, 2014. Lake benthic algae: toward an understanding of their ecology. Freshw. Sci. 33:475-486.

Cardinale BJ, Palmer MA, Swan CM, Brooks S, Poff NL, 2002. The influence of substrate heterogeneity on biofilm metabolism in a stream ecosystem. Ecology 83:412-422.

Carpenter SR, Lodge DM, 1986. Effects of submersed macrophytes on ecosystem processes. Aquat. Bot. 26:341-370.

Choi JY, Jeong KS, La GH, Kim SK, Goo GJ, 2014. Sustainment of epiphytic microinvertebrate assemblage in relation with different aquatic plant microhabitats in freshwater wetlands (South Korea). J. Limnol. 73:11-16.

Compère $\mathrm{P}, 1976$. [Algues de la région du lac Tchad. V : Chlorophycophytes (1ère partie)].[Article in French]. Cah. Orstom Hydrobiol. 10:77-118.

Cuassolo F, Batisdas-Navarro M, Balseiro E, Modenutti B, 2011. Leachates and elemental ratios of macrophytes and benthic algae of an Andean high altitude wetland. J. Limnol. 70:1-9.

Dodds WK, Biggs BJF, 2002. Water velocity attenuation by stream periphyton and macrophytes in relation to growth form and architecture. J. N. Am. Benthol. Soc. 21:2-15.

Felisberto SA, Rodrigues L, 2010. Periphytic algal community in artificial and natural substratum in a tributary of the Rosana reservoir (Corvo Stream, Paraná State, Brazil). Acta Scient. Biol. Sci. 32:373-385.

Ferreira FA, Mormul RP, Biolo S, Rodrigues L, 2011. [Podostemum rutifolium subsp. rutifolium como estruturador da comunidade de algas perifíticas em um rio neotropical].[Article in Portoguese]. Rodriguésia 62: 813-825.

FUNCEME (Fundação Cearense de Meteorologia e Recursos Hídricos), 2012. Accessed on: 21.02.2012. Available from: http://www.funceme.br/index.php/areas/tempo/downloaddeseries-historicas/

Guariento RD, Caliman A, Esteves FA, Enrich-Prast A, Bozelli RL, Farjalla VF, 2007. Substrate-mediated direct and indirect effects on periphytic biomass and nutrient content in a tropical coastal lagoon, Rio de Janeiro, Brazil. Acta Limnol. Bras. 19:331-340.
Hammer Ø, Harper DAT, Ryan PD, 2001. PAST: Palaeontological statistics software package for education and data analysis. Palaeontol. Electron. 4:1-9.

Hansen JP, Wikström SA, Axemar H, Kautsky L, 2011. Distribution differences and active habitat choices of invertebrates between macrophytes of different morphological complexity. Aquat. Ecol. 45:11-22.

Hinojosa-Garro D, Mason CF, Underwood GJC, 2010. Influence of macrophyte spatial architecture on periphyton and macroinvertebrate community structure in shallow water bodies under contrasting land management. Fundam. Appl. Limnol. 177:19-37.

Jones JI, Moss B, Eaton JW, Young JO, 2000. Do submerged aquatic plants influence periphyton community composition for the benefit of invertebrate mutualists? Freshwater Biol. 43:591-604.

Lalonde S, Downing JA, 1991. Epiphyton biomass is related to lake trophic status, depth, and macrophyte architecture. Can. J. Fish. Aquat. Sci. 48:2285-2291.

Lobo E, Leighton G, 1986. [Estructuras comunitarias de las fitocenosis planctonicas de los sistemas de desembocaduras de rios y esteros de la zona central de Chile].[Article in Spanish]. Rev. Biol. Mar. 22:1-29.

Lowe RL, 1996. Periphyton patterns in lakes, pp. 57-76. In: RJ Stevenson, Bothwell ML and RL Lowe (eds.), Algal ecology: freshwater benthic ecosystems. Academic Press, San Diego.

Lowe RL, LaLiberte GD, 2007. Benthic stream algae: distribution and structure, pp. 327-356. In: FR Hauer and GA Lamberti (eds.), Methods in stream ecology, Academic Press, London.

Lucena-Moya P, Duggan IC, 2011. Macrophyte architecture affects the abundance and diversity of littoral microfauna. Aquat. Ecol. 45:279-287.

Mateucci S, Colma A, 1982. [La metodologia para el estudo de la vegetacion].[Book in Spanish]. Série Biologia: 168 pp.

Messyasz B, Kuczyńska-Kippen N, 2006. Periphytic algal communities: a comparison of Typha angustifolia L. and Chara tomentosa L. beds in three shallow lakes (West Poland). Pol. J. Ecol. 54:15-27.

Messyasz B, Kuczyńska-Kippen N, Nagengast B, 2009. The epiphytic communities of various ecological types of aquatic vegetation of five pastoral ponds. Biologia 64:88-96.

Mizuno T, 1968. Ilustrations of the freshwater plankton of Japan. Osaka: Hoikusha, 351 pp.

Mormul RP, Thomaz SM, Silveira MJ, Rodrigues L, 2010. Epiphyton or macrophyte: which primary producer attracts the snail Hebetancylus moricandi? Am. Malacol. Bull. 28:127133.

Mulderij G, Donk EV, Roelofs JGM, 2003. Differential sensitivity of green algae to allelopathic substances from Chara. Hydrobiologia 491:261-271.

Murakami E, Bicudo DC, Rodrigues L, 2009. Periphytic algae of the Garças Lake, Upper Paraná River floodplain: comparing the years 1994 and 2004. Braz. J. Biol. 69:459-468.

Newell GE, Newell RC, 1977. Marine plankton: a practical guide. Hutchinson, London: 244 pp.

Pacini A, Mazzoleni S, Battisti C, Ricotta C, 2009. More rich means more diverse: Extending the 'environmental heterogeneity hypothesis' to taxonomic diversity. Ecol. Indic. 9:1271-1274. 
Parra OO, Gonzalez M, Delarrosa V, 1983. [Manual taxonômico del fitoplancton de águas continentales: com especial referência al fitoplâncton de Chile. V. Chlorophyceae. Parte 1: Volvocales, Tetrasporales, Chlorococcales y Ulotricales]. [Book in Spanish]. Editoral Universidad de Concepción: $151 \mathrm{pp}$.

Pinheiro MIT, Campos JNB, Studart TMC, 2011. [Conflitos por águas e alocação negociada: o caso do vale dos Carás no Ceará].[Article in Portuguese]. Rev. Adm. Pública 45:16551672.

Round FE, Crawford RM, Mann DG, 1992. The diatoms: biology and morphology of the genera. Cambrigde University Press, New York: 747 pp.

Sant'Anna CL, 1984. [Chloroccales (Chlorophyceae) do Estado de São Paulo, Brasil].[Book in Portuguese]. Stauss \& Cramer, Hirschberg: 348 pp.

Schneck F, Schwarzbold A, Melo AS, 2011. Substrate roughness affects stream benthic algal diversity, assemblage composition, and nestedness. J. N. Am. Benthol. Soc. 30: 1049-1056.

Soares MCS, Sophia MG, Huszar VLM, 2007. Phytoplankton flora of two rivers in Southeast Brazil: Paraibuna and Pomba Rivers, Minas Gerais. Rev. Bras. Bot. 30:433-450.

Sophia MG, Dias ICA, Araújo AM, 2005. Chlorophyceae and Zygnematophyceae from the Turvo State Forest Park, state of Rio Grande do Sul, Brazil. Iheringia 60:25-47.

StatSoft Inc. Statistica for Windows. Versão 7.0. Tulsa, 2004.

Stevenson RJ, 1996. An introduction to algal ecology in freshwater benthic habitats, pp. 3-30. In: RJ Stevenson, ML Both- well and RL Lowe (eds.), Algal ecology: freshwater benthic ecosystems, Academic Press, San Diego.

Sultana M, Asaeda T, Azim ME, Fujino T. 2010. Morphological responses of a submerged macrophyte to epiphyton. Aquat. Ecol. 44:73-81.

Thomaz SM, Cunha ER, 2010. The role of macrophytes in habitat structuring in aquatic ecosystems: methods of measurement, causes and consequences on animal assemblages' composition and biodiversity. Acta Limnol. Bras. 22:218-236.

Thomaz SM, Dibble ED, Evangelista LR, Higuti J, Bini LM, 2008. Influence of aquatic macrophyte habitat complexity on invertebrate abundance and richness in tropical lagoons. Freshwater Biol. 53:358-367.

Vercellino IS, Bicudo DC, 2006. [Sucessão da comunidade de algas perifíticas em reservatório oligotrófico tropical (São Paulo, Brasil): comparação entre período seco e chuvoso].[Article in Portuguese]. Rev. Bras. Bot. 29:363-377.

Villeneuve A, Montuelle B, Bouchez A, 2010. Influence of slight differences in environmental conditions (light, hydrodynamics) on the structure and function of periphyton. Aquat. Sci. 72:33-44.

Wehr JD, Sheath RG, 2003. Freshwater algae of North America: ecology and classification. Academic Press, San Diego: 950 p.

Whittaker RH, 1975. Community and ecosystems. MacMillan Publ., New York: 385 pp.

Xavier MB, 1994. [Criptógamas do Parque Estadual das Fontes do Ipiranga, São Paulo, SP. Algas, 5: Euglenophyceae (Euglenaceae pigmentadas)].[Article in Portuguese]. Hoehnea 21:47-73. 